\title{
A northern refugium of the Mediterranean water shrew Neomys anomalus in Słowiński National Park (N Poland)
}

\author{
LESZEK RYCHLIK, AGNIESZKA STACHOWIAK, URSZULA NOWAK and PAWEŁ KARDYNIA \\ Department of Systematic Zoology, Institute of Environmental Biology, Adam Mickiewicz University, \\ Umultowska 89, 61-614 Poznań, Poland \\ Corresponding author: Leszek Rychlik, e-mail: 1rychlik@amu.edu.pl
}

(Received on 5 April 2011; Accepted on 9 August 2011)

\begin{abstract}
The influence of recent anthropogenic and climatic changes on the distribution or population size of individual species should be especially pronounced at the boundaries of their geographical ranges. Therefore, in summers 2008-2010, we live-trapped small mammals and analysed habitat features on 14 study plots comprising various wet habitats of Słowiński National Park (at the Baltic coast in northern Poland) in order to recognize the current distribution and population size of Neomys anomalus Cabrera, 1907 in its northernmost population in Europe. $N$. anomalus was, however, captured only on one plot - a wet, unmown meadow crossed by unkempt drainage ditches, situated on the Gać Peninsula (Półwysep Gacki). This result, compared to historical data, suggests that neither the abundance of $N$. anomalus has increased nor its range has been extended. We give a detailed description of the habitat in this study plot. The information can be useful in the protection of this rare shrew species with very specific habitat requirements.
\end{abstract}

Keywords: Neomys anomalus, habitat selection, unmown meadows, distribution, protected species

\section{INTRODUCTION}

The protected and poorly investigated Mediterranean water shrew Neomys anomalus Cabrera, 1907 is one of the rarest and most interesting species of shrews (Mammalia: Soricidae) in Poland. This species is slightly smaller but morphologically very similar to the Eurasian water shrew Neomys fodiens (Pennant, 1771). The latter is much more frequent and widespread throughout the country. Both species are semi-aquatic but $N$. anomalus is less adapted to this lifestyle: it has proportionately smaller feet with fewer fringes and a shorter tail with a shorter keel on its ventral side than N. fodiens (Pucek 1984). In the Białowieża Forest, N. anomalus occurs more frequently in ecotones than in dense forest stands or open sedge swamps, and prefers wet places but located at some distance from deep water (RYCHLIK 2000). It dives less often than N. fodiens and ineffectively forages in deep water (RYCHLIK 1997; SOARES 
\& Rychlik 2009), thus its diet includes a smaller proportion of aquatic invertebrates and it mostly consists of typical terrestrial organisms (e.g. earthworms and terrestrial beetles) and of prey living in shallow water and mud (CHURCHFIELD \& RYCHLIK 2006).

The geographical range of $N$. anomalus in Poland is divided into 3 populations: north-western in Pomerania, southern in the Sudetes and Carpathians, and eastern in the Białowieża Forest (PuCEK \& RACZYŃski 1983). Due to human-made and climatic changes, in recent decades a number of species have changed their geographic ranges, also among shrews (Frey 1992; Vogel et al. 2002; SiEMERs et al. 2006). This also may apply to $N$. anomalus, which is a stenothermic species (RYCHLIK 1998) and could extend its range. Therefore, we focused on its northernmost population, located in Słowiński National Park (SNP). The Park comprises various types of terrestrial and aquatic ecosystems, including those preferred by water shrews: wet meadows and sedge swamps crossed by numerous drainage ditches.

Data on the presence of this species in SNP are scarce. OBERTANIEC (1977) found $N$. anomalus in pellets of barn owls Tyto alba, collected in Smołdzino (located outside SNP). Also LESIŃSKI \& RUSIN (1996) found remains of $N$. anomalus in barn owl pellets from the village of Gać (south-eastern part of SNP). In both cases, it is possible that the owls hunted their prey in the Park. However, OBERTANiEC (1977) trapped intensively small mammals on 6 plots located in the western part of SNP and did not capture any specimen of $N$. anomalus. Only HeJduk (1998) caught 10 specimens on wet meadows north of Gać. The data suggest that in the past the population of $N$. anomalus in SNP was very dispersed and small.

The existence of suitable habitats, as well as climate warming and anthropogenic changes in recent decades (e.g. ceased drainage, abandonment of some agricultural lands) might have contributed to an increase in its local population size or extension of its range. Therefore, there was a need to examine the various habitats in different parts of SNP in order to recognize the current distribution and population size of the Mediterranean water shrew in the Park.

\section{MATERIAL AND METHODS}

In 2008-2010 in late July or early August we trapped small mammals and analysed habitats on 14 study plots in eastern and central parts of SNP (Fig. 1). The investigations covered a variety of habitats (mostly wet) characteristic of SNP (Table 1). Plant names used in habitat descriptions follow MireK et al. (2002).

The trapping was conducted using the CMR method with individual marking of all small mammals by trimming numbers, i.e. small areas of fur on animals' back and/ or sides. Box traps of 'dziekanówka' type (http://pulapki.republika.pl/foto/gryzon3. jpg, produced by PPUH A. Marcinkiewicz) were used on all the study plots. They were placed in 10-m intervals in lines (along drainage ditches or water channels) or in grids $10 \mathrm{~m} \times 10 \mathrm{~m}$. In addition, cone pitfalls were used on 2 plots. Minced beef was used as bait for shrews in both types of traps. Oat flakes, grains, sunflower seeds and croutons fried in oil were also placed in the same traps to lure rodents. On plots where shrews were caught, the traps were set at 18:00, checked every $2 \mathrm{~h}$, and blocked 
NEOMYS ANOMALUS IN SŁOWIŃSKI NATIONAL PARK

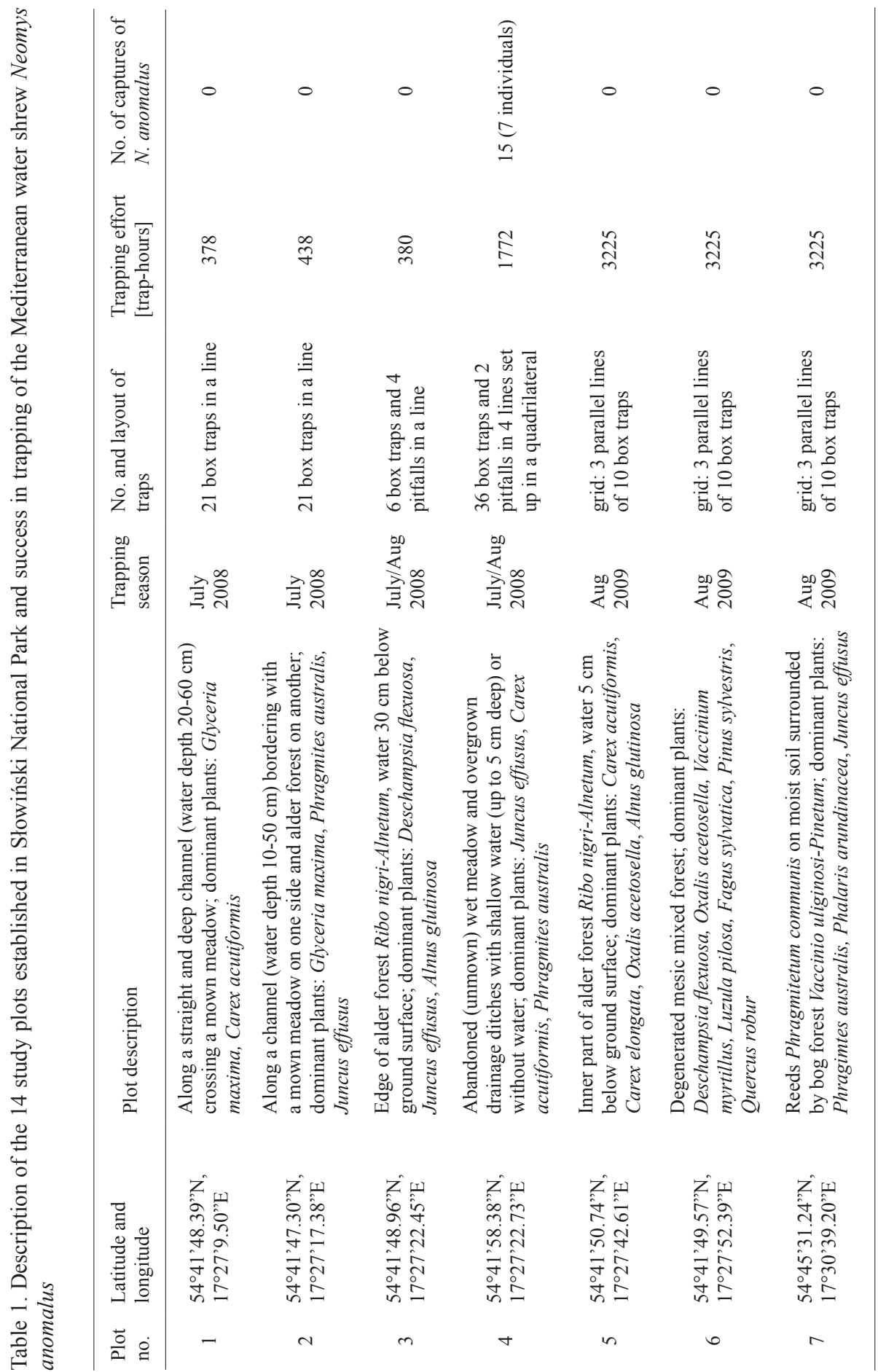




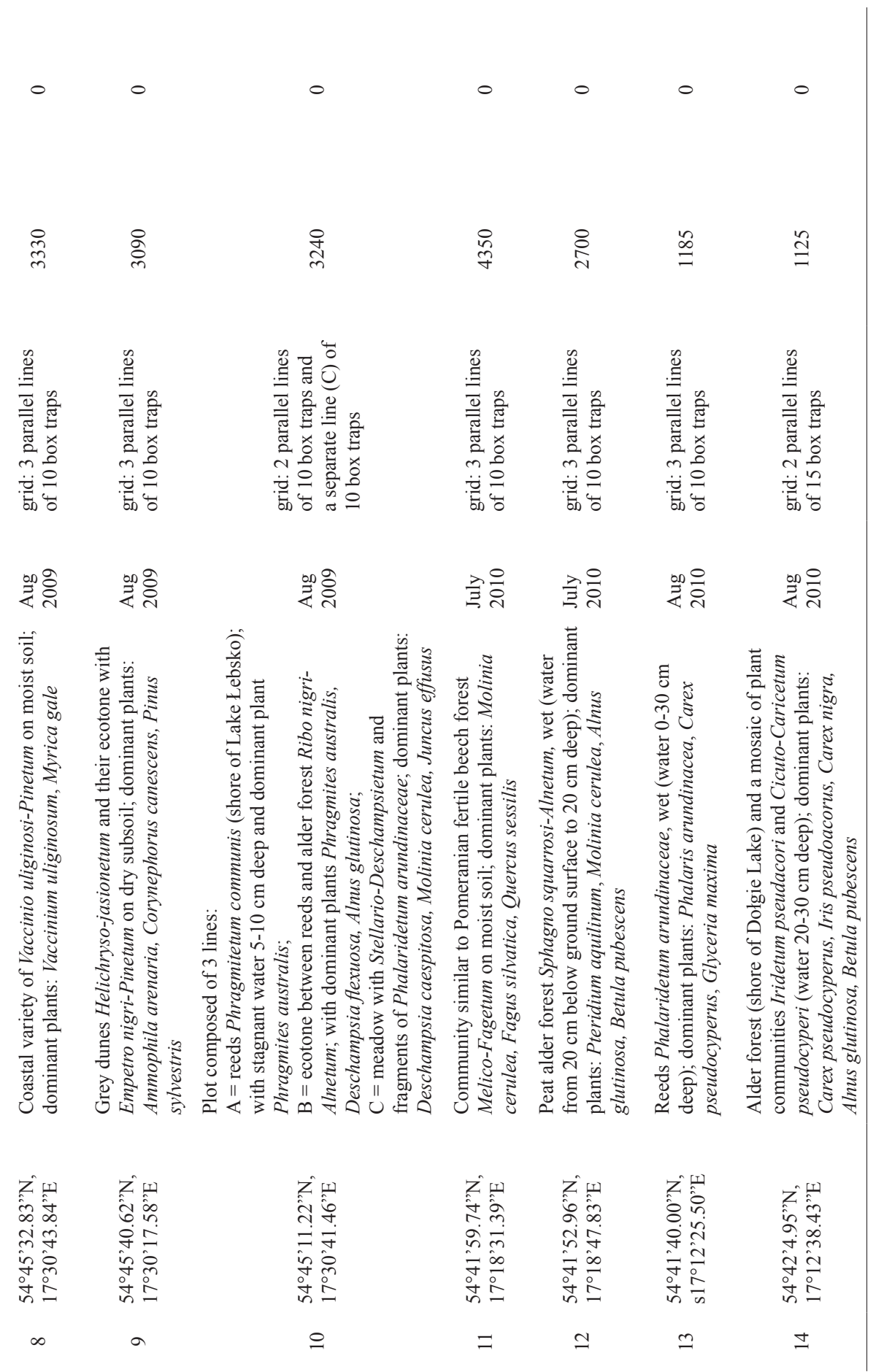


around 4:00. On plots dominated by rodents (i.e. where shrews did not occur or appeared sporadically), traps were open non-stop and checked 4 times per day (about $0: 00,8: 00,15: 00$ and 21:00) to increase the chance of detection of $N$. anomalus during the day.

Trapped mammals, after weighing (in a plastic bag on a portable Pesola spring balance) and determination of their species, age, gender, and sexual activity, were immediately released at the place of capture. Animals captured for the first time were marked by fur trimming as mentioned above. The terminal part of tail (approximately $5 \mathrm{~mm}$ ) of 5 specimens of $N$. anomalus and 5 of $N$. fodiens were cut for genetic research prior to release. Genetic results will be presented in a separate article.

\section{RESULTS}

Among the 14 study plots on which trapping was conducted, Mediterranean water shrews were trapped only on plot no. 4 (Table 1), situated on the Gać Peninsula (Fig. 1). Seven individuals were caught there (2 adult females and 5 juveniles). These animals were captured, in total, 15 times during 9 nights.

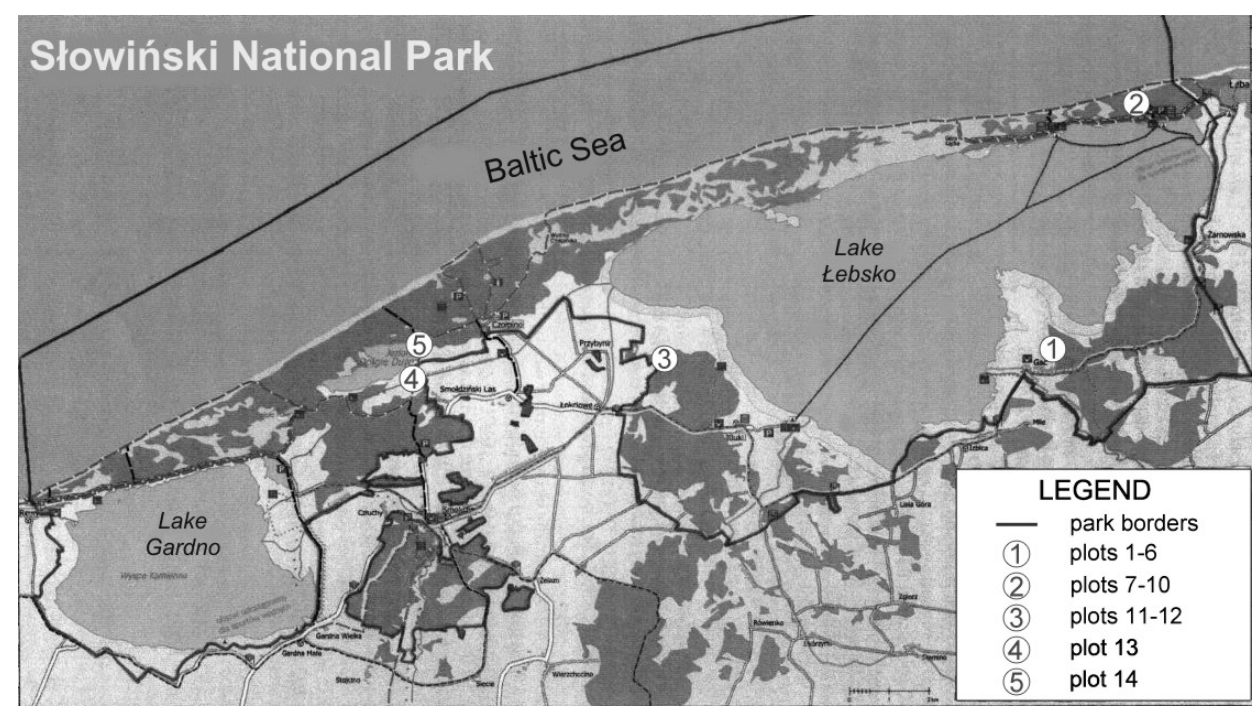

Fig. 1. Location of the 14 study plots in Słowiński National Park (see Table 1 for characteristic of the plots). Map modified from FLOREK (2008)

Plot no. 4 was a wet, unmown meadow crossed by unkempt drainage ditches of various water depth (or dried out). In places differing in soil moisture and plant cover, traps were positioned in 4 lines forming a quadrilateral, with lines R, T, and D running along the ditches, and line $\mathrm{S}$ intersecting the meadow. 
Line R (where 2 individuals of $N$. anomalus were caught) bordered a ditch filled with water approximately $5 \mathrm{~cm}$ deep. Lemna trisulca dominated in water, while $M o$ linia caerulea along the bank. The wet meadow, adjacent to the ditch, was overgrown with lush and very diverse grasses and herbs, such as Juncus effusus, Rumex hydrolapatum, Deschampsia caespitosa, Plantago lanceolata, Potentilla repens, and Carex acutiformis.

Line $\mathrm{T}$ (where $N$. anomalus was captured 4 times) ran along a dried-up ditch (although water table was just below the ground surface) overgrown with high wetland plants (mainly Typha latifolia, Phragmites australis, Juncus effusus, and Phalaris arundinacea). Urtica dioica, Rumex hydrolapatum, and Juncus effusus dominated outside the ditch.

Line D (where $N$. anomalus was trapped 7 times) bordered a dried-up ditch with a drier substratum than on the previous lines (water table was approximately $10 \mathrm{~cm}$ below the ground surface). Typha latifolia, Phalaris arundinacea, Molinia cerulea, and Juncus effusus dominated in the ditch, while low plants, such as Potentilla repens, Dactylis glomerata, Plantago lanceolata, Mentha arvensis, prevailed outside the ditch (Fig. 2). There was also a single alder tree Alnus glutinosa, near which $N$. anomalus was captured 4 times.

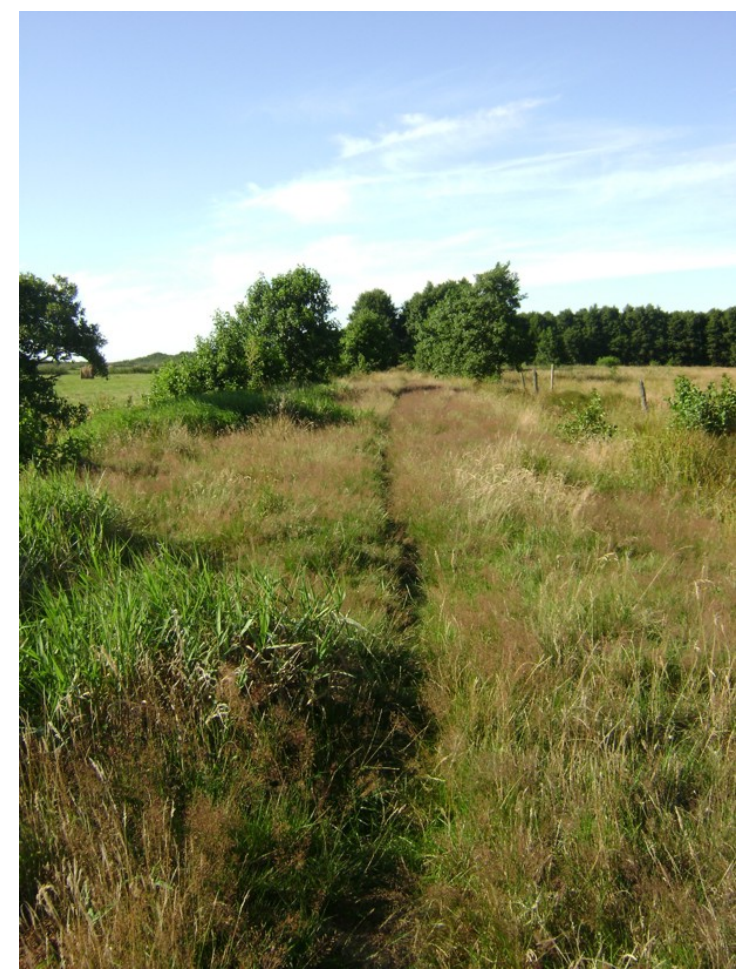

Fig. 2. Line D on plot no. 4 - the habitat preferred by Neomys anomalus in Słowiński National Park (photo A. Stachowiak) 
Line S ( 2 captures of $N$. anomalus) crossed the meadow, with water level approximately $30 \mathrm{~cm}$ below the ground surface. Vegetation was dominated by herbs like Juncus effusus, Lychnis flos-cuculi, Phalaris arundinacea, Polygonum persicaria, and Trifolium arvense.

The common features of the all 4 lines were: dense (unmown) vegetation, wet ground, and lack of deep water, either stagnant or flowing. Full descriptions of the lines and of plots no. 1-14 are available in the work by STACHOWIAK (2009).

Although no specimen of $N$. anomalus was caught on the remaining 13 plots, we trapped there many individuals of various species of rodents (a total of 193 captures) and shrews (42 captures; RYchlik et al., in prep.). Those included both the semiaquatic $N$. fodiens and shrews smaller than $N$. anomalus (i.e. Sorex araneus and $S$. minutus).

\section{DISCUSSION}

For the first time the presence of Neomys anomalus was reported for SNP by Obertaniec during his MSc study performed in 1975-1976 (OBERTANIEC 1977; PuCEK \& RACZYŃSKi 1983). OBERTANIEC (1977) found 69 specimens of N. anomalus in pellets of the barn owl Tyto alba collected in Smołdzino (now placed at the western border of SNP), and perhaps a few individuals in Czołpino (in the central part of SNP) - it is not clearly stated in his MSc thesis. At the same time, in his intensive snap-trapping sessions on 6 plots located in the western part of SNP and covering 6 different biotopes, no individual of $N$. anomalus was caught (OBERTANIEC 1977). In 1991, Hejduk (1998) captured 10 animals of this species in live-traps set along the drainage ditches across the wet meadows north of the village of Gać (south-eastern part of SNP). LESIŃSKI \& RUSIN (1996) found 15 individuals of $N$. anomalus in barn owl's pellets collected in 1993 in the same village. The present study, carried out using similar methods and on the same site as in HeJDuk's study, showed that after 17 years the population of $N$. anomalus still exists on the Gać Peninsula.

At this site, $N$. anomalus selects wet microhabitats, but not flooded or immediately adjacent to deep water. These microhabitats provide a dense cover of vegetation (thanks to not mowing the meadow). On the other hand, $N$. anomalus rather avoids places with high wetland vegetation. Similar microhabitat preferences were displayed by this species in the Białowieża Forest (RYснLik 2000, 2001). Thus, as previously suggested by RYCHLIK \& PUCEK (1995), also on the basis of the present results it can be concluded that leaving unmown wet meadows and sedge swamps seems to be indispensable for maintenance of this species.

It is interesting that a large proportion of our captures of $N$. anomalus took place near a single tree standing in an open area. A similar trend in this species (and also in other shrews, e.g. Sorex araneus and S. minutus, and the root vole Microtus oеconomus) was observed by RYcHLIK $(2000,2001)$, who suggested that roots of trees and the gaps between tussocks of sedges and the tree trunks provide the animals with good shelters and nesting dens.

In total, 5 juveniles and 2 adult females of $N$. anomalus were captured on plot no. 4 . This means that the habitat of this plot provided suitable conditions and a sufficient 
food base for $N$. anomalus to live and reproduce there. Thus, the population is likely to continue its existence in that area, unless the habitat conditions are disturbed.

The lack of $N$. anomalus in the other moist habitats investigated in SNP is worrying, especially because it seems to be absent even from the areas adjacent to plot no. 4. Our captures of other species of small mammals on all plots (including the semiaquatic $N$. fodiens and shrews smaller than $N$. anomalus; RYCHLIK et al., in prep.) prove that our traps were not placed in wrong places and were sensitive enough to capture $N$. anomalus. Thus, the presence of this species only on one site indicates very specific habitat requirements of $N$. anomalus. This suggests also that despite the observed changes in climate and the use of meadows by man, neither the abundance of $N$. anomalus has increased nor its range has extended dramatically. However, it does not seem possible to us that the only site in the entire SNP inhabited by this species is a small area of the Gać Peninsula, especially that OBERTANIEC (1979) detected the presence of this species in several unprotected locations not far from SNP. Therefore, further, more detailed studies in different parts of the Park and adjacent areas are needed.

Acknowledgements: We are very grateful to K. Kowalski, D. Matuszyk, N. Osten-Sacken, R. Zwolak, and E. Eichert for help in field work; to K. Woźniak (director of SNP), I. Izydorek and D. Staniaszek (from SNP) for allowing us to conduct our studies in the Park and for help; to M. Banach for making his field station in Gać available; to A. Brzeg and M. Wojterska for botanical consultations; and to K. Sęk for help in preparation of the manuscript. The research was supported by grant no. SFRH/BD/31602/2006 from the Science and Technology Foundation (Portuguese Ministry of Science, Technology and Higher Education) and the budget of the Department of Systematic Zoology (Faculty of Biology AMU, Poznań).

\section{REFERENCES}

Churchfield S., Rychlik L. 2006. Diets and coexistence in Neomys and Sorex shrews in Białowieża Forest, eastern Poland. J. Zool., Lond. 269: 381-390.

FLOREK W. 2008. Słowiński Park Narodowy. 40 lat ochrony unikatowej przyrody i kultury [Słowiński National Park. 40 years of protection of the unique nature and culture]. Wydawnictwo Słowińskiego Parku Narodowego, Smołdzino (in Polish).

Frey J. 1992. Response of a mammalian faunal element to climatic changes. J. Mammal. 73: 43-50.

HeJduk J. 1998. Morfogenetyczne zróżnicowanie populacji rzęsorka mniejszego Neomys anomalus (Cabrera, 1907) w Polsce [Morphogenetic differentiation of populations of the Mediterranean water shrew Neomys anomalus (Cabrera, 1907) in Poland]. PhD thesis, Wydział Biologii i Nauk o Ziemi, Uniwersytet Łódzki, Łódź (in Polish).

Lesiński G., Rusin A. 1996. Pokarm płomykówki Tyto alba w Słowińskim Parku Narodowym [Food of the barn owl Tyto alba in the Słowiński National Park]. Chrońmy Przyr. Ojcz. 52: 103-106 (in Polish).

Mirek Z., Pięroś-Mirkowa H., Zając A., Zając M. 2002. Flowering plants and pteridophytes of Poland. A checklist. In: Biodiversity of Poland, (Mirek Z., Ed.), vol. I, pp. 1-442, W. Szafer Institute of Botany PAS, Kraków.

OBertaniec J. 1977. Badania ilościowe ugrupowań gryzoni i ssaków owadożernych na terenie Słowińskiego Parku Narodowego i okolic w latach 1975-1976 [Quantitative analysis of communities of rodents and insectivorous mammals in the Słowiński National Park and its vicinity in 1975-1976]. MSc thesis, Akademia Pomorska, Słupsk (in Polish). 
Obertaniec J. 1979. Występowanie rzęsorka mniejszego, Neomys anomalus Cabrera, 1907 (Insectivora) na Pomorzu [Occurrence of Neomys anomalus Cabrera, 1907 (Insectivora) in Pomerania]. Przeg. Zool. 23: 172-173 (in Polish).

Pucek Z. 1984. Klucz do oznaczania ssaków Polski [Key to determination of mammals of Poland]. PWN, Warszawa (in Polish).

Pucek Z., RaczyŃski J. 1983. Atlas rozmieszczenia ssaków w Polsce [Atlas of distribution of mammals in Poland]. PWN, Warszawa (in Polish).

RYCHLIK L. 1997. Differences in foraging behaviour between water shrews: Neomys anomalus and Neomys fodiens. Acta Theriol. 42: 351-386.

RYchLIK L. 1998. Evolution of social systems in shrews. In: Evolution of shrews (WóJCIK J. M., WoLSAN M., Eds), pp. 347-406, Mammal Research Institute PAS, Białowieża.

RychLiK L. 2000. Habitat preferences of four sympatric species of shrews. Acta Theriol. 45, Suppl. 1: $173-190$.

RYchLIK L. 2001. Habitat preferences of water shrews and root vole coexisting along a stream in Białowieża Forest. Säugetierkundl. Inform. 5: 99-112.

Rychlik L., Pucek Z. 1995. Biotope requirements of Neomys fodiens and Neomys anomalus in lowland zone of their sympatric occurrence. In: Proceedings of the "Seminar on the biology and conservation of European desmans and water shrews (Galemys pyrenaicus, Desmana moschata, Neomys spp.)", Ordesa, Spain, 7-10 June 1995, vol. 32, pp. 88-89, Council of Europe, Strasbourg, T-PVS (95).

Siemers J. L., Chen Y. R., Canestorp K. M., Sovell J. R., Cornelisse K. L. 2006. Range expansion of the least shrew (Cryptotis parva) in Colorado. Southwest. Natur. 51: 267-269.

SoAres H. M., Rychlik L. 2009. Differences in swimming and diving abilities between two sympatric species of water shrews: Neomys anomalus and Neomys fodiens (Soricidae). J. Ethol. 27: 317-325, DOI 10.1007/s10164-008-0122-z.

Stachowiak A. 2009. Ryjówkowate (Soricidae) wilgotnych siedlisk Słowińskiego Parku Narodowego [Shrews (Soricidae) of wet habitats in Słowiński National Park]. BSc thesis, Uniwersytet im. A. Mickiewicza, Poznań (in Polish).

Vogel P., Jutzeler S., Rulence B., Reutter B. A. 2002. Range expansion of the greater whitetoothed shrew Crocidura russula in Switzerland results in local extinction of the bicoloured white-toothed shrew C. leucodon. Acta Theriol. 47: 15-24. 